\title{
Abiding worries over federal health research
}

$\mathrm{T}$ he Peer Review Working Group convened by the Canadian Institutes of Health Research (CIHR) recommends the agency partially reverse course on its heavily criticized virtualization technologies.

But three chairs of the CIHR's College of Reviewers - the 17 researchers who manage peer review — are concerned the working group's recommendations won't restore the integrity of Canadian health research.

The 13-member Peer Review Working Group was commissioned in July, shortly after federal Health Minister Dr. Jane Philpott asked the CIHR — which is entrusted with a billion-dollar annual health research budget — to address anger over a new online peer review process that all but eliminated face-toface peer reviews.

Previously, about $80 \%$ of all grant applications were reviewed by upward of 50 face-to-face panels. The CIHR claimed that scrapping the panels would be more "sustainable," and that scientists could instead do the peer reviews remotely using virtual technologies.

In June, more than 1000 scientists signed a petition protesting the changes.

This protest proved potent: in a July statement, CIHR President Dr. Alain Beaudet said that virtualization resulted in an "alarming increase in reports of poor quality online reviews and lack of appropriate online discussions." He added that "CIHR cannot afford to lose the confidence of the scientific community."

CIHR then established the Peer Review Working Group, which recommended on Sept. 14 that about $60 \%$ of applications should be eliminated after being assessed by four independent reviewers. The group recommended that only the surviving $40 \%$ of applications be reviewed by around 30 face-to-face, subject-specific peer review panels.

This means reinstatement of half the face-to-face reviews and half the number of face-to-face panels, said Paul Kubes, the working group's chair and a professor at the University of Calgary's Faculty of Medicine.

CIHR has agreed to implement the group's recommendations "where possi-

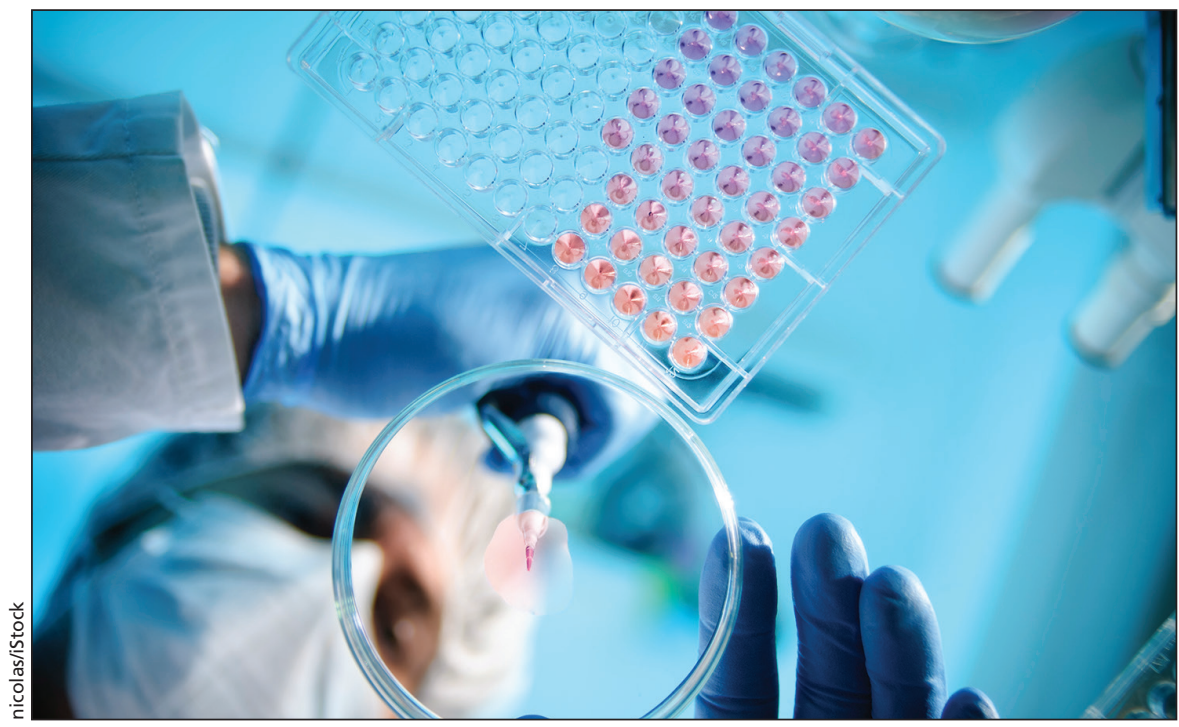

The Canadian Institutes of Health Research has been asked to reinstate face-to-face peer review panels for about $40 \%$ of applications.

ble," Kubes said. In a statement emailed to the CMAJ, Beaudet said the changes that CIHR is now implementing "reflect the collective efforts, sound advice and shared commitment of the health research community to implement a trusted and fair peer review process."

Nine of the 17 chairs of the CIHR's College of Reviewers - including Kubes - told CMAJ they wholly endorse the recommendations.

But three of the chairs who support the recommendations are, alongside Kube, also members of the working group itself. "Since I was part of [the working group], I come in with some biased opinions," said McGill University biochemistry professor Morag Park.

Four chairs declined to comment, including Eric Brown, Canada Research Chair in Microbial Chemical Biology at McMaster University, who explained "I don't think it's a best practice for members of the working group to be commenting on these recommendations." One college chair was unavailable for comment.

The remaining three members of the College of Reviewers expressed strong reservations about the recommendations, including Dr. Mark Narod, at the University of Toronto's Department of Medicine. He said the decision to eliminate $60 \%$ of applications without review by face-to-face panels is a mistake.
"This amounts to a dramatic reduction in accountability and it sends the signal to scientists that their applications are simply not valued," Narod said. "I think the system is too far gone without a complete overhaul. If this happened in the United States, the head of the [National Institutes of Health] would be fired."

In response, Kubes says funding for more panels is lacking, and that his group recommended the CIHR implement oversight mechanisms that allow for rejected applications to be "rescued" if College of Reviewer members or their delegates intervene.

College member Peter Jones, Canada Research Chair in Functional Foods and Nutrition, at the University of Manitoba, questioned the recommendation to halve the number of subject-specific peer-review panels. About 20\% of nutrition researcher applications were once approved, but the recent reduction in review panels meant the elimination of a panel dedicated to nutrition. There was a hundred-fold reduction in approvals for nutrition research.

Kubes said nutritionists must now compete for funding from a panel not solely dedicated to nutrition. - Paul Webster, Toronto, Ont.

With files from Barbara Sibbald, CMAJ.

CMAJ 2016. DOI:10.1503/cmaj.109-5333 